INTERNATIONAL JOURNAL
OF
PHARMACEUTICAL SCIENCES
RESEARCH

Received on 02 March, 2017; received in revised form, 08 July, 2017; accepted, 12 July, 2017; published 01 October, 2017

\title{
HISTORICAL OVERVIEW, DEVELOPMENT AND NEW APPROACHES IN DESIGN OF ANGIOTENSIN CONVERTING ENZYME INHIBITORS AND ANGIOTENSIN RECEPTOR ANTAGONISTS PART II
}

Irina Drapak ${ }^{1}$, Tatyana Tsapko ${ }^{2}$, Lina Perekhoda ${ }^{2}$, Natalia Bereznyakova ${ }^{* 2}$ and Olga Kiz ${ }^{2}$

Department of General ${ }^{1}$, Bioinorganic, Physical and Colloidal Chemistry, Danylo Halytsky Lviv National Medical University, Lviv, Ukraine.

Department of Medicinal Chemistry ${ }^{2}$, National University of Pharmacy, Kharkiv, Ukraine.

Keywords:

Renin-angiotensin system (RAS), ACE inhibitors, Renin inhibitors, $\mathrm{AT}_{1}$ antagonists, $\mathrm{AT}_{2}$ antagonists, SAR analysis

\section{Correspondence to Author:}

Dr. Natalia Bereznyakova

Associate Professor, Department of Medicinal Chemistry, National University of Pharmacy, Kharkiv, Ukraine.

E-mail: natalibereznyakova@gmail.com

\begin{abstract}
The renin-angiotensin system (RAS) plays an important role in pathogenesis of hypertension, congestive heart failure, and chronic renal failure. In addition to a discussion of the current understanding of the chemical structures and the modes of action of angiotensin converting enzyme (ACE) inhibitors and angiotensin receptor (ATR) antagonists, review includes their SAR analysis and chemical modification for improving their activity. Nowadays different modeling strategies are underway to develop tailor made molecules with the best of properties among nonpeptide renin inhibitors, dual action receptor antagonists (e.g. angiotensin and endothelin antagonists, ACE/NEP inhibitors, $\mathrm{AT}_{1} / \mathrm{TxA}_{2}$ antagonists, balanced $\mathrm{AT}_{1} / \mathrm{AT}_{2}$ antagonists), triple inhibitors. In the first part is given an overview of various ACE inhibitors. The second part is devoted to overview of angiotensin receptor antagonists. The advances that have been made, new opportunities, and future directions of design and development of these classes have been discussed.
\end{abstract}

INTRODUCTION: The angiotensin II receptor blockers (ARBs) represent a newer class of antihypertensive agents comparing with angiotensin-converting enzyme (ACE) inhibitors. Their mechanism of action differs from that of the ACE inhibitors, which also affect the renin angiotensin system (RAS). The ARBs were developed to overcome several of the deficiencies of ACE inhibitors: competitive inhibition of ACE results in a reactive increase in renin and angiotensin I levels, which may overcome the blockade effect;

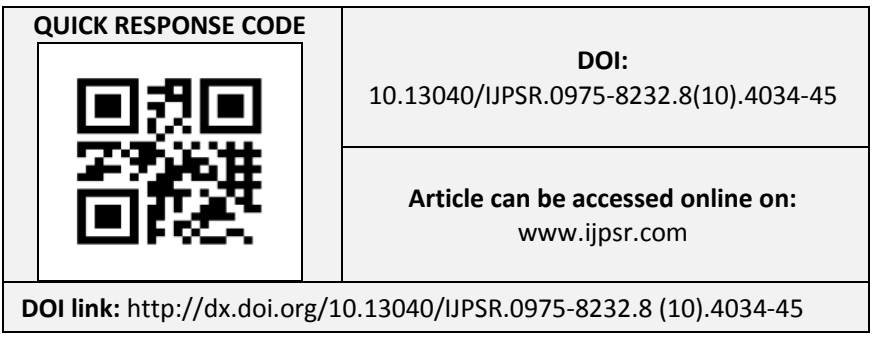

ACE is a relatively nonspecific enzyme that has substrates in addition to angiotensin I, including bradykinin and other tachykinins, and thus, inhibition of ACE may result in accumulation of these substrates; production of angiotensin II can occur through non-ACE pathways as well as through the primary ACE pathway, and these alternative pathways are unaffected by ACE inhibition; specific adverse effects are associated with ACE inhibitor effects on the enzyme; and ARBs offer more complete angiotensin II inhibition by interacting selectively with the receptor site ${ }^{1}$. Today, we know that more biochemical pathways are affecting the conversion of angiotensinogen to angiotensin II; although angiotensin II affects mainly two $G$ protein-coupled receptor subtypes, namely $\mathrm{AT}_{1} \mathrm{R}$ and $\mathrm{AT}_{2} \mathrm{R}$, at least four different subtypes have been identified (designated as $A_{1} R$, $\mathrm{AT}_{2} \mathrm{R}, \mathrm{AT}_{3} \mathrm{R}$ and $\mathrm{AT}_{4} \mathrm{R}$ ). 
Also, the different metabolites of angiotensin II, which form after proteolytic degradation of the parent molecule, present biological activity. In addition, angiotensin II has high binding affinity to neurolysin which in turn may affect significantly the activity on RAS. The action of angiotensin II on $\mathrm{AT}_{1} \mathrm{R}$ was the first to be studied in detail, while the mode of action of $\mathrm{AT}_{2} \mathrm{R}$ remained elusive for a long time owing to the lack of ligands that selectively target this receptor as also due to its low expression. Furthermore, new functions of the two receptors have been revealed. It is now shown that $\mathrm{AT}_{1} \mathrm{R}$ and $\mathrm{AT}_{2} \mathrm{R}$ present opposing biological functions, e.g. $\mathrm{AT}_{2} \mathrm{R}$ has anti-proliferative properties, while $\mathrm{AT}_{1} \mathrm{R}$ facilitates angiogenesis and cellular proliferation. Besides the classical functions mediated by the $\mathrm{AT}_{1} \mathrm{R}$ like vasoconstriction, proliferation of vascular smooth muscle and cardiac cellular growth, a direct correlation has been identified between the upregulation of $\mathrm{AT}_{1} \mathrm{R}$ and the immunosuppression and invasiveness state in many cancer types, establishing $\mathrm{AT}_{1} \mathrm{R}$ as a potential cancer drug target.

There are other functions associated by $\mathrm{AT}_{2} \mathrm{R}$, for instance, $\mathrm{AT}_{2} \mathrm{R}$ adopts a protective role in pathological conditions such as tissue injury and inflammation, diabetic neuropathy, stroke damage, diabetes type 2, spinal cord injury and cancer. As with renin and ACE inhibitors, extensive rational design plans had to be implemented by researchers working both in industry and academia to discover
$\mathrm{AT}_{1} \mathrm{R}$ antagonists. Initially, efforts were mainly focused on peptides, but owing to the known disadvantages that peptides encounter they could not enter clinical trials or the market as drugs ${ }^{2}$.

\section{Peptide Mimetics: Design of Agonists /} Antagonists: The first prototypical compound was saralasin, an octapeptide. Saralasin as well as other peptide analogs demonstrated the ability to reduce blood pressure; however, these compounds lacked oral bioavailability and expressed unwanted partial agonist activity. More recent efforts have utilized peptide mimetics to circumvent these inherent problems with peptide based antagonists.

Peptide mimetics have been defined as molecules which mimic the action of peptides, have no peptide bonds, and a molecular weight less than 700 Daltons. In comparison with peptide drugs, peptide mimetics have numerous pharmaceutical advantages. Foremost among these are increased bioavailabilities and increased duration of action. The majority of known peptide mimetics have been discovered by random screening techniques; however, this process is costly, labor intensive, and unpredictable. However, these studies provided valuable SAR knowledge. From peptides, the scientists have been led to small organic molecules that mimicked the C-terminal segment of angiotensin II. The culmination of these efforts was the 1995 approval of losartan, a non-peptide angiotensin II receptor antagonist ${ }^{3}$.

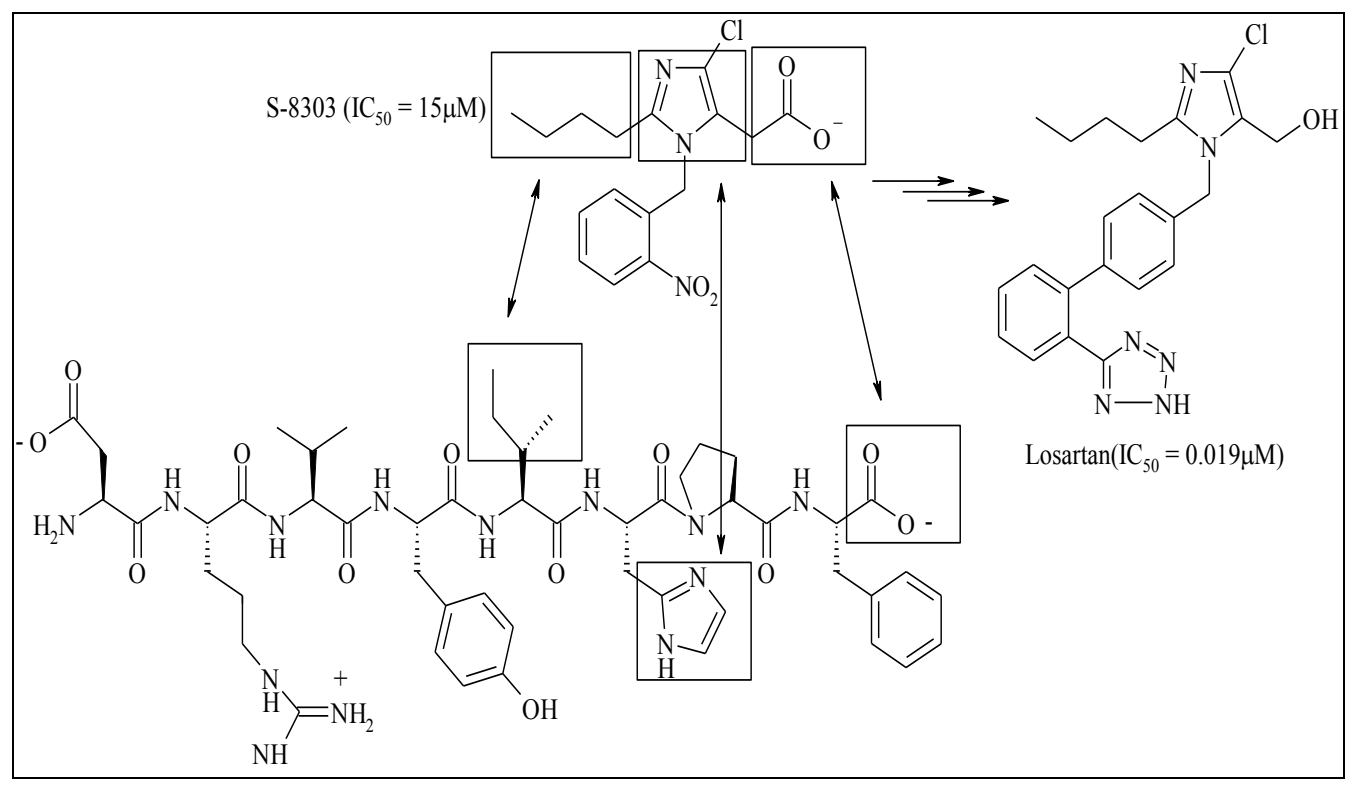

FIG. 1: COMPUTERIZED MOLECULAR MODELING OVERLAP OF ANGIOTENSIN II WITH THE STRUCTURE OF S-8308 AND MODELING OF LOSARTAN FROM S-8308 
The first $\mathrm{AT}_{1} \mathrm{R}$ antagonist that entered the market was losartan. Its development can be traced back to two 1982 patent publications ${ }^{4}$ which described the antihypertensive effects of a series of imidazole-5acetic acid analogs. These compounds are exemplified by S-8308 (Fig. 1) and were later found to specifically block the angiotensin II receptor.

A computerized molecular modeling overlap of angiotensin II with the structure of S-8308 revealed three common structural features. The ionized carboxylate of S-8308 correlated with the Cterminal carboxylate of angiotensin II, the imidazole ring of S-8308 correlated with the imidazole side chain of the His ${ }_{6}$ residue, and the $n$ butyl group of S-8308 correlated with the hydrocarbon side chain of the $\mathrm{Ile}_{5}$ residue $^{3}$.

From S-8308, a number of molecular modifications were carried out in an attempt to improve receptor binding and lipid solubility. These changes resulted in preparation of losartan, a compound with high receptor affinity $\left(\mathrm{IC}_{50}=0.019 \mu \mathrm{M}\right)$ and oral activity (Fig. 1).

The success of losartan followed eight more derivatives constituting the class of SARTANs or ARBs (Fig. 2) ${ }^{2}$.

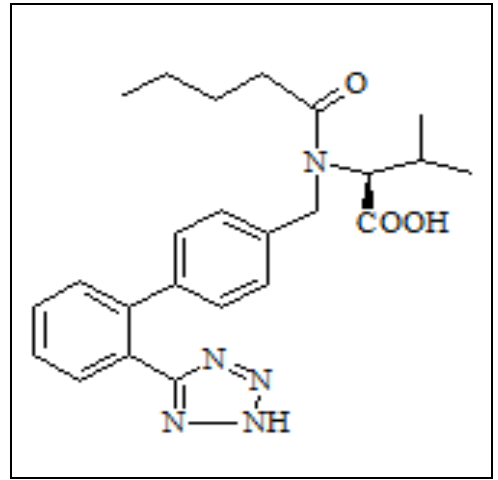

VALSARTAN

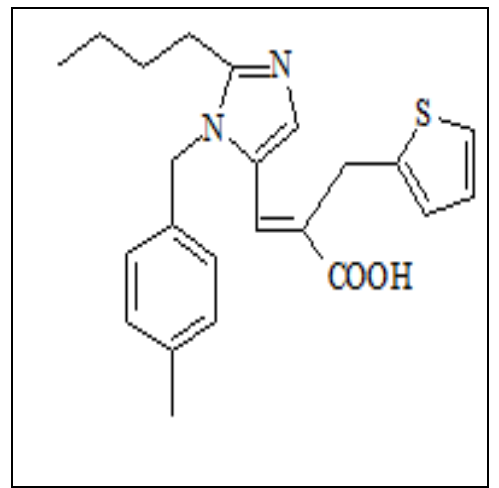

EPROSARTAN

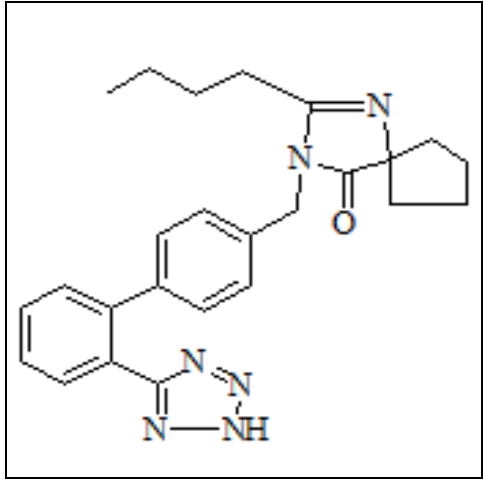

IRBESARTAN

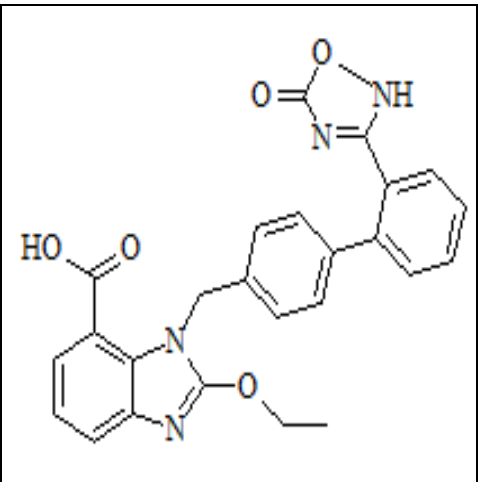

AZILARTAN

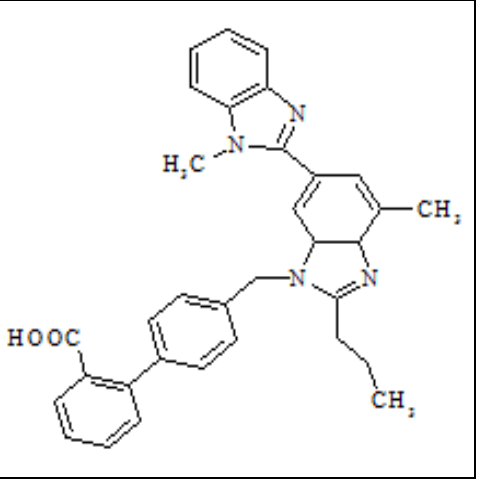

TELMISARTAN

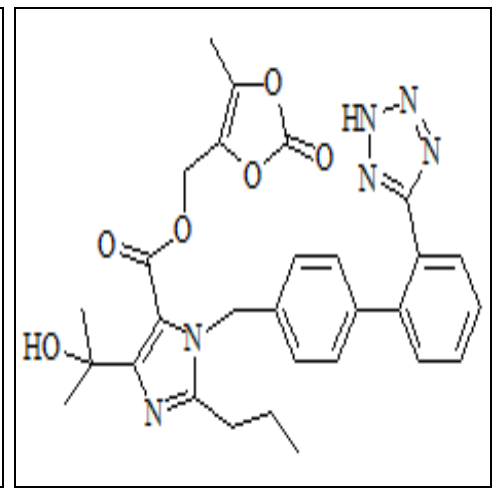

OLMESARTAN<smiles>CCCCc1nc(C)c(CC(=S)N(C)C)c(=O)n1Cc1ccc(-c2ccccc2-c2nn[nH]n2)cc1</smiles>

FILMASARTAN

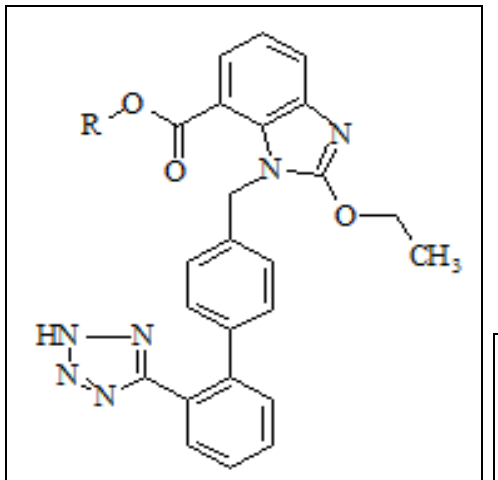

CANDESARTAN CILEXETIL
$\mathrm{R}=\mathrm{Cr}_{\mathrm{O}}^{\circ} \mathrm{I}_{\mathrm{CH},}^{\circ}$

$\mathrm{R}=\mathrm{H}$

FIG. 2: CHEMICAL STRUCTURES OF LOSARTAN ANALOGS 
Valsartan, irbesartan, candesartan, telmisartan, azilsartan, fimasartan and olmesartan are biphenyl analogs of losartan (Fig. 2). Each of these compounds has a structural feature unique from those seen in losartan. Valsartan, named for the valine portion of the compound, is the first nonimidazole containing angiotensin II antagonist, and is slightly more potent $\left(\mathrm{IC}_{50}=0.0089 \mu \mathrm{M}\right)$ than losartan. Candesartan cilexitil and telmisartan are both contain benzimidazole rings which allow for enhanced hydrophobic binding and an increase in potency, as compared to losartan. Candesartan cilexitil is a prodrug which is rapidly and completely metabolized to the active metabolite, candesartan (Fig. 2).

Eprosartan was developed using a different hypothesis than that for losartan (Fig. 3). Similar to the rationale for losartan, the carboxylic acid of S-
8308 was thought to mimic the $\mathrm{Phe}_{8}$ (i.e. Cterminal) carboxylate of angiotensin II. The benzyl group of S-8308 was proposed to be an important structural feature which mimicked the aromatic side chain of $\mathrm{Tyr}_{4}$ present in the agonist. Thus the major structural change was not extension of the Nbenzyl group but enhancement of the compound's ability to mimic the $\mathrm{C}$-terminal end of angiotensin II.

This was accomplished by substituting the 5-acetic acid group with an $\alpha$-thienylacrylic acid. In addition, a para-carboxylate, a functional group investigated during the development of losartan, was also added. The thienyl ring isosterically mimics the $\mathrm{Phe}_{8}$ phenyl ring of angiotensin II and along with the para-carboxylate is responsible for the excellent potency $\left(\mathrm{IC}_{50}=0.0015 \mu \mathrm{M}\right)$ of this compound $^{3}$.

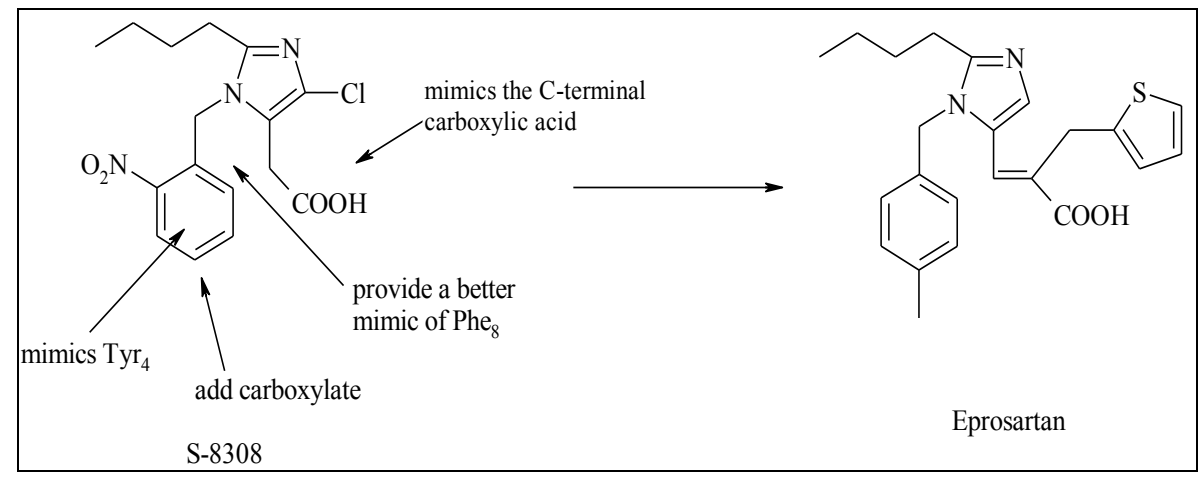

FIG. 3: STRUCTURAL MODIFICATION OF S-8308 TO DEVELOP EPROSARTAN

Amongst the other derivatives of SARTANs should mention embusartan (BAY 10-6734), with a dihydropyridinone ring, orally active $\mathrm{AT}_{1}$ antagonist ${ }^{5}$; KRH-594 an acyliminothiadiazoline, selective $\mathrm{AT}_{1}$ antagonist ${ }^{6}$; KT3-671 (now known as KD3-671) has a seven-membered ring fused to imidazole ring. KT3-671 is potent, competitive, selective $\mathrm{AT}_{1}$ antagonist (Table 1) ${ }^{7}$.

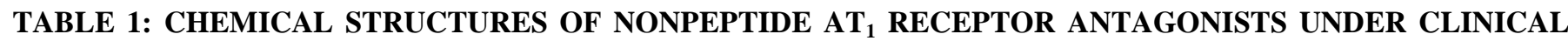
TRIALS

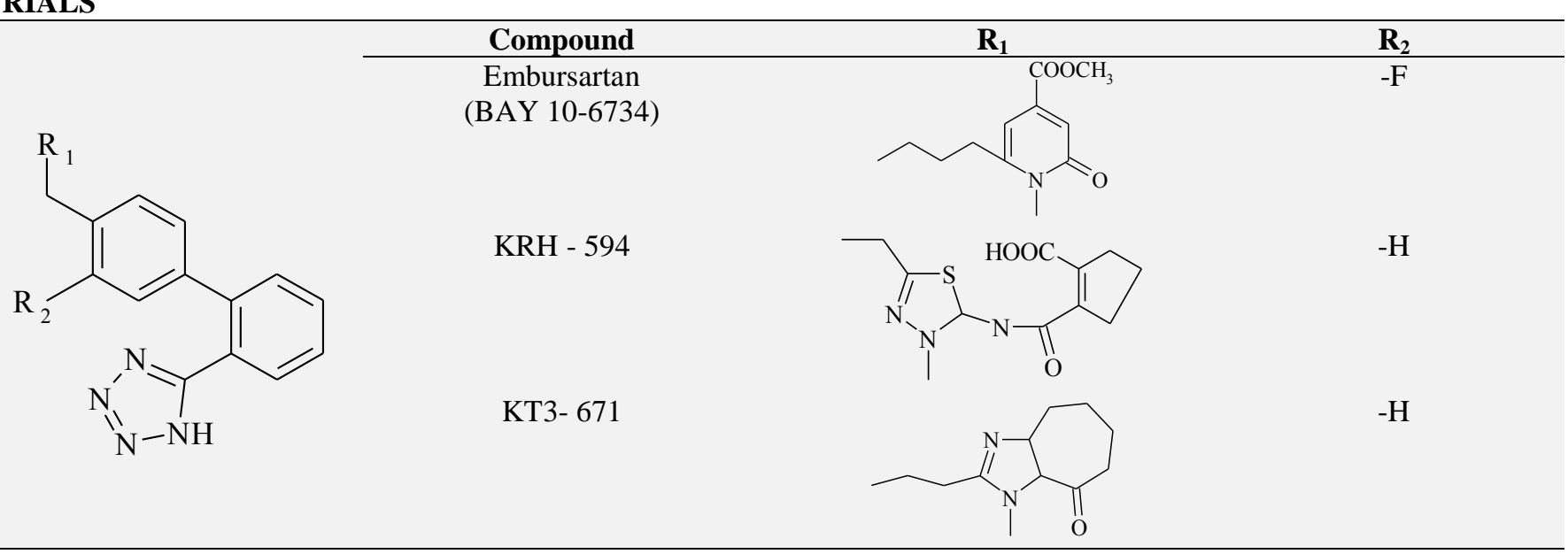


Losartan, valsartan, irbesartan, and eprosartan all show selectivity for this $\mathrm{AT}_{1}$ subtype receptor. They prevent and reverse all of the known effects of angiotensin II, including rapid and slow pressor responses, stimulatory effects on the peripheral sympathetic nervous system, CNS effects, release of catecholamines, secretion of aldosterone, direct and indirect renal effects, and all growth-promoting effects. Replacement of the imidazole ring of losartan with heterocyclic ring also led to synthesis of many nonpeptide $\mathrm{AT}_{1}$ antagonists. In-house 5nitrobenzimidazole derivatives with varying substituents at 2-position, which have been designed, and synthesized have shown modest affinities for angiotensine II AT1 receptor ${ }^{8}$.

The imidazole ring has been successfully replaced by fused heterocyclic ring systems also.
Imidazo[4,5-b]pyridine derivatives i.e. L-158809 (Fig. 4) ${ }^{9}$, which has shown highly selective $\mathrm{AT}_{1}$ receptor antagonist activity in halothaneanesthetized in-vivo canine model ${ }^{10}$. YM 358 (Fig. 4) has long-lasting antihypertensive effect ${ }^{11}$ with no rebound hypertension on discontinuation of therapy. It is 3-10 times more potent than losartan and is a competitive $\mathrm{AT}_{1}$ antagonist as shown in invitro and in-vivo rat, rabbit and canine hypertension models ${ }^{12}$. HR 720 (Fig. 4), now named as fonsartan, has a sulfonylurea replacement for the tetrazole moiety and 4-alkylthio substituent at imidazole ring. It is highly potent (10 times more potent than losartan) and selective noncompetitive $\mathrm{AT}_{1}$ antagonist in isolated rabbit aorta and human gastroepiploic arteries ${ }^{13}$.

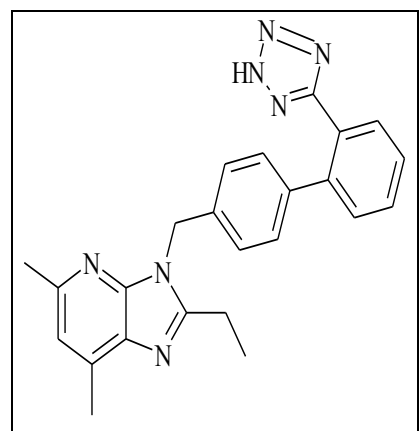

L158809

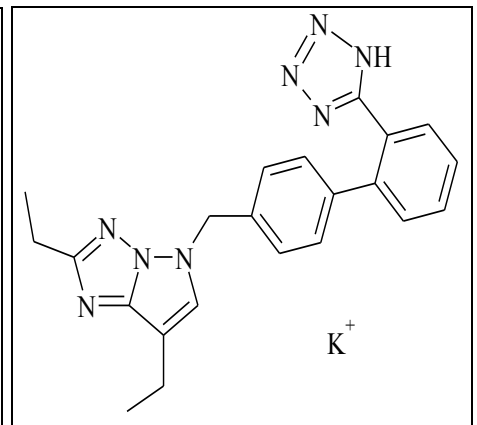

YM 358

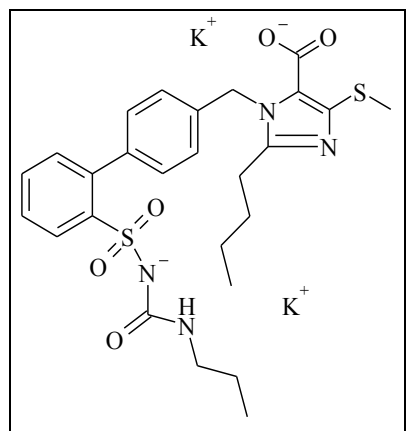

HR 720

FIG. 4: CHEMICAL STRUCTURES OF L-158809, YM 358, HR 720

Novel Synthetic Molecules Acting on the $\mathbf{A T}_{\mathbf{1}} \mathbf{R}$ : Agelis et al., 14, 15 synthesized a series of symmetrically bis-substituted imidazole analogues bearing at $\mathrm{N}-1$ and $\mathrm{N}-3$ two biphenyl moieties ortho-substituted either with tetrazole or carboxylate groups. Among them, the imidazolium (BV6, Fig. 5) showed superior antagonistic activity and receptor affinity to that of losartan.

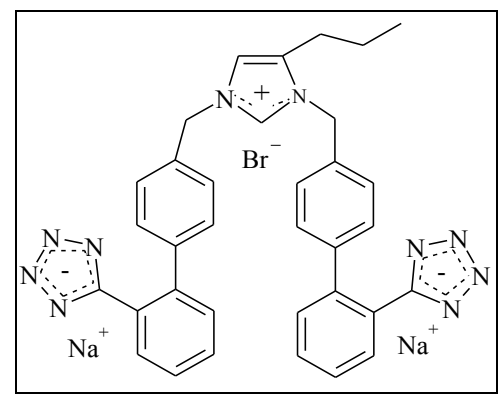

FIG. 5: CHEMICAL STRUCTURE OF BV6

Compounds A and B (Fig. 6) were synthesized by Zhang et al., ${ }^{16}$, and are promising selective $\mathrm{AT}_{1} \mathrm{R}$ antagonists. Da et al., ${ }^{17}$ synthesized fluorine substituted derivatives of losartan, valsartan and irbesartan with carboxylic acid group as replacement to the known potent tetrazole moiety at the 2'-biphenyl position. The biphenyl C (Fig. 6) showed an efficient and long lasting effect in reducing blood pressure which lasted more than 24 $\mathrm{h}$ at a dose of $10 \mathrm{mg} / \mathrm{kg}$ in spontaneous hypertensive rats, which was much better than controls losartan and valsartan. In addition to antihypertensive property, the biphenyl $\mathrm{C}$ also inhibited prostate cancer in vitro and in vivo. The 5nitrobenzimidazole (compound A, Fig. 7) exerts high nanomolar and durable activity $\left(\mathrm{IC}_{50}=1.03 \pm\right.$ $0.26 \mathrm{nM}$ ) in vascular smooth muscle cells. This compound bears an indole benzoic ring instead of the biphenyl scaffold with an acidic segment attached at the ortho-position, (a common feature to commercial drugs except eprosartan that contains only one phenyl ring) ${ }^{18}$. 


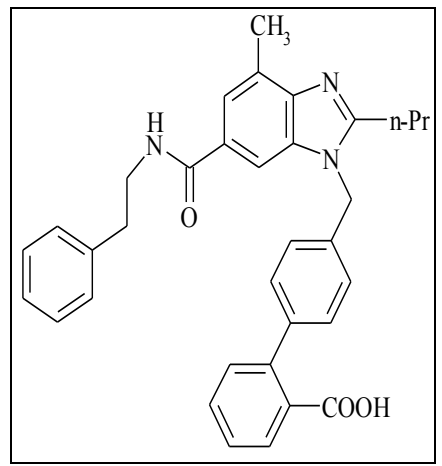

A

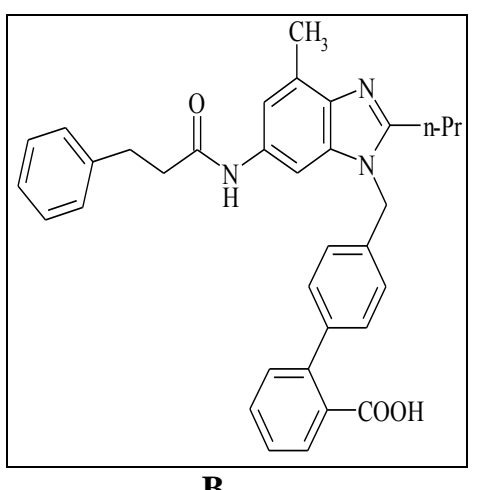

B

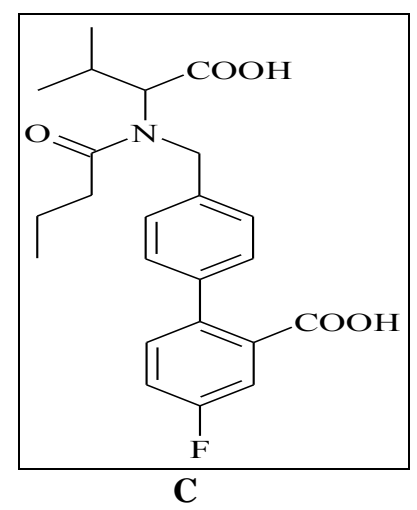

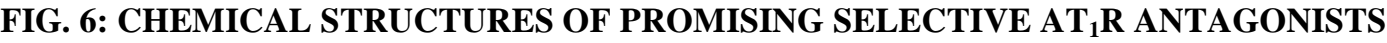

A series of compounds based on the $\alpha_{1^{-}}$B (Fig. 7) exhibited hypotensive activity more or adrenoreceptor antagonist drug urapidil and less similar to losartan ${ }^{19}$. molecular modeling were synthesized. Compound

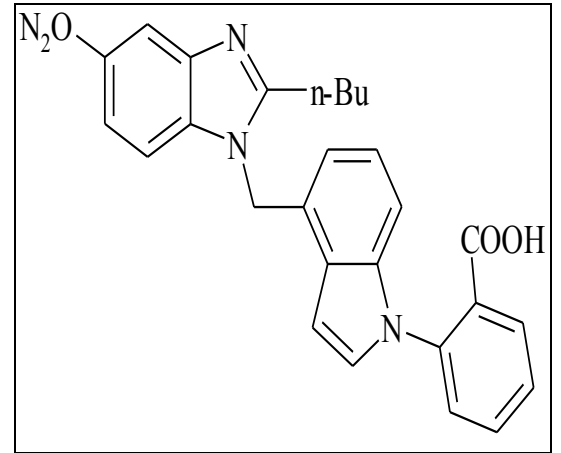

A

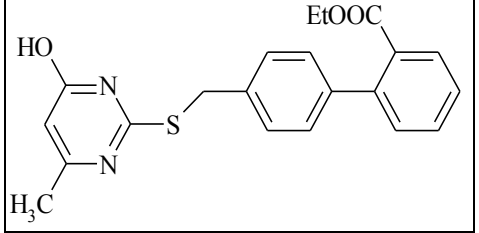

B

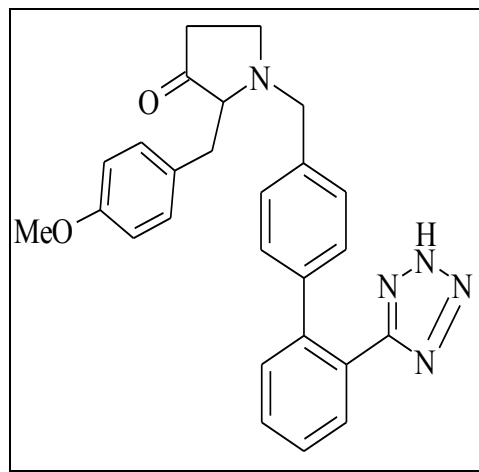

C

FIG. 7: CHEMICAL STRUCTURES OF SOME PERSPECTIVE COMPOUNDS WITH HYPOTENSIVE ACTIVITY

New $\mathrm{AT}_{1} \mathrm{R}$ antagonists were designed and evaluated based on a central pyrrolidine system bearing biphenyl-tetrazoles or biphenylcarboxylic acids at the N-12, C-3 and C-4 positions. Among them compound $\mathrm{C}$ (Fig. 7) was the most promising and had 2-fold higher hypotensive activity than losartan and similar level of antihypertensive activity to losartan with $\mathrm{LD}_{50}$ value of $117 \mu \mathrm{g} / \mathrm{kg}$ demonstrating in this way the high safety margin of the compound. The compound was evaluated in vivo for hypotensive activity on normotensive rats 20 .

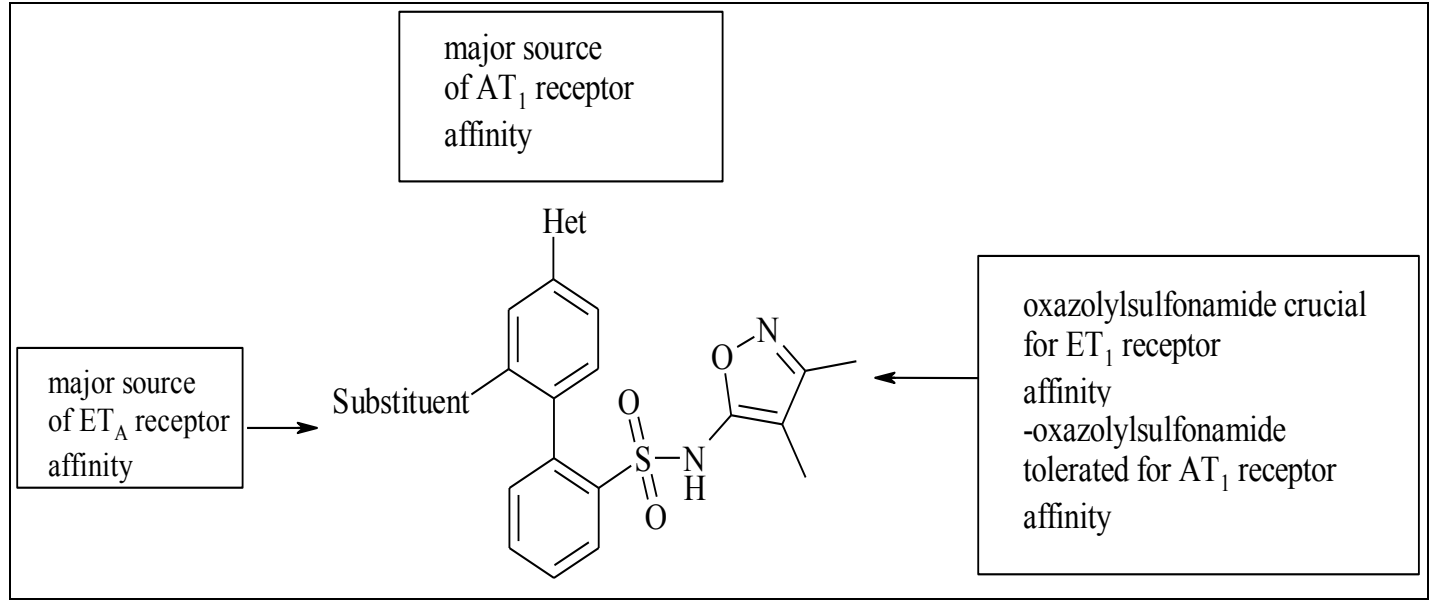

Multi-target Drugs: Following the molecular hybridization approach combining two discrete drugs in one molecule, numerous multi-target drug molecules, have been designed and synthesized with beneficial effects. Some such examples are outlined below. 
Angiotensine II potentiates the production of endothelin (ET) and conversely endothelin augments the synthesis of angiotensine II. Thus, a combination $\mathrm{AT}_{1} / \mathrm{ET}_{\mathrm{A}}$ receptor antagonist may have a greater efficacy and broader utility compared with each drug alone. By rational drug design, a biphenyl $\mathrm{ET}_{\mathrm{A}}$ receptor blocker was modified to acquire $\mathrm{AT}_{1}$ recetor antagonism (Table 2). Out of the synthesized series of 6 compounds
(A-F), compounds $\mathrm{C}$ and $\mathrm{D}$ are novel agents for treating a broad spectrum of patients with essential hypertension and other cardiovascular diseases ${ }^{21}$. The compound $\mathrm{F}$ demonstrates superiority over irbesartan (an $\mathrm{AT}_{1}$-receptor antagonist) in the normal SHR model of hypertension in a dosedependent manner, demonstrating the synergy of $\mathrm{AT}_{1}$ and $\mathrm{ET}_{\mathrm{A}}$ receptor blockade in a single molecule ${ }^{22}$.

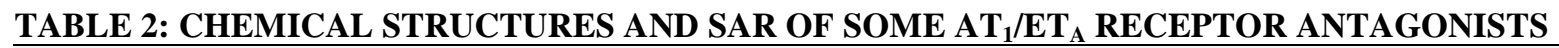

\begin{tabular}{|c|c|c|c|c|c|c|}
\hline Compound & $\mathbf{A}$ & B & C & D & $\mathbf{E}$ & $\mathbf{F}$ \\
\hline Het & & & & & & \\
\hline Substituent & $\mathrm{H}$ & $\mathrm{H}$ & & OEt & & $\mathrm{CH}_{2} \mathrm{OEt}$ \\
\hline
\end{tabular}

Compound BMS-1 or (butyryl-[2'-(4, 5-dimethylisoxazol-3- ylsulfamoyl)- biphenyl- 4- ylmethyl]amino)-N-isopropyl-3-methyl-butyramide (Fig. 8) is also a potent dual acting $\mathrm{AT}_{1}$ and $\mathrm{ET}_{\mathrm{A}}$ receptor antagonist. As exemplified by 2-(butyryl-[2'-(4fluoro-5-methyl-isoxazol-3-ylsulfamoyl)-biphenyl-
4- ylmethyl]- amino)- $n$ - isopropyl- 3- methylbutyramide (BMS-3) (Fig. 9), a fluorinated analog of BMS-1, BMS-3 could be metabolized by both cytochrome $\mathrm{P}$ (CYP) enzymes, CYP2C9 and CYP3A4, and thus avoiding the reliance on a single CYP enzyme for metabolic clearance ${ }^{23}$.
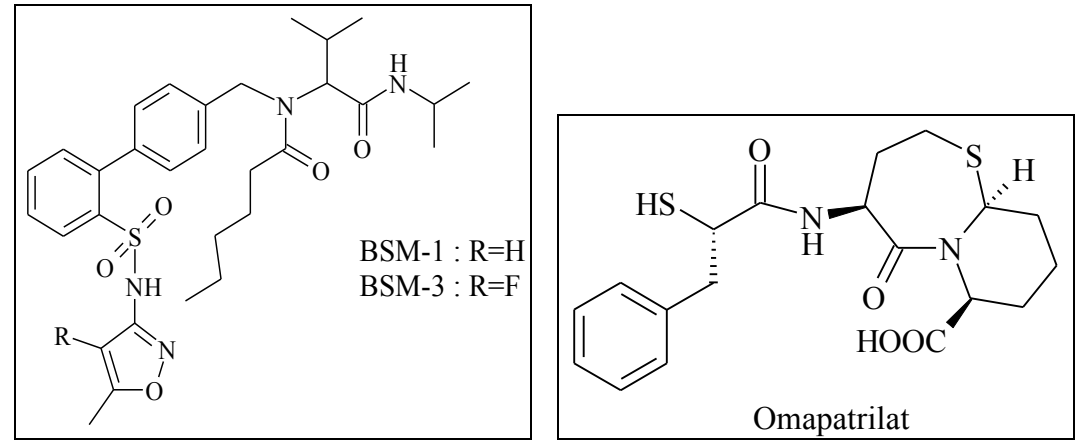

FIG. 8: CHEMICAL STRUCTURE OF THE NEW DUAL-ACTION RECEPTOR ANTAGONISTS

Earlier, losartan and EXP 3174 and recently, irbesartan have been shown to inhibit thromboxane $\mathrm{A}_{2}$ induced contractions in canine coronary arteries by inhibiting the vascular $\mathrm{TxA}_{2} / \mathrm{PGH}_{2}$ receptor. EK112 is a new combined $\mathrm{AT}_{1}$ and thromboxane $\mathrm{A}_{2}$ receptor blocking agent. The antagonistic effect of these agents on the thromboxane $\mathrm{A}_{2}$ receptor may contribute to the long-termblood pressure lowering effects of $\mathrm{AT}_{1}$ antagonists in hypertension ${ }^{24}$. Omapatrilat (Fig. 8) is the ACE/NEP inhibitor that has been most extensively studied. Omapatrilat is a potent, long acting dual metalloproteinase inhibitor $\left(\mathrm{ACE} \mathrm{IC} \mathrm{I}_{50}=5 \mathrm{nmol} / 1, \mathrm{NEP} \mathrm{IC} 50=8 \mathrm{nmol} / \mathrm{l}\right)$ and exerts prolonged antihypertensive effects in several experimental models of hypertension including the DOCA salt hypertensive model and the $\mathrm{SHR}^{25}$.

Fosidotrilat, sampatrilat, Z13752A (GW660511X, Fig. 9) are some more novel ACE/NEP inhibitors. The latter compound has also shown efficacy against ventricular fibrillation and tachycardia in a canine model of coronary artery occlusion which is attributed to the protective effects of increased bradykinin levels ${ }^{26}$. 


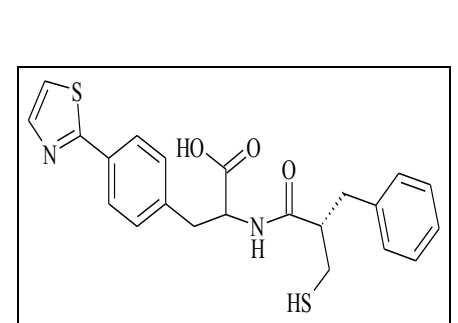

Z13752A

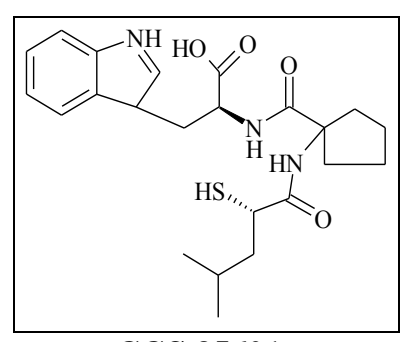

CGS 35601
FIG. 9: CHEMICAL STRUCTURES OF Z13752A AND CGS 35601

The concept of triple vasopeptidase inhibition has recently gained interest. In this case, ACE/NEP inhibition is supplemented by additional inhibition of endothelin converting enzyme (ECE) blocking the conversion of big ET-1 to ET-1, a vasoconstrictor and profibrotic agent acting in synergy with angionensine II. Preliminary studies in experimental settings such as the SHR have shown that triple therapy, with CGS 35601 (Fig. 9), dose dependently reduced blood pressure, decreased angionensine II and ET-1 concentrations as well as proANP, but increased big ET-1, ANP and bradykinin. These data suggest that CGS 35601, a triple vasopeptidase inhibitor, may represent a novel class of antihypertensive drugs and may have the potential to reduce morbidity and mortality from cardiovascular disorders, diabetes and subsequent renal complications ${ }^{27}$.

Mojarrad et al., described ${ }^{28}$ an attempt to design and synthesize molecules that combine structural elements present in $\mathrm{AT}_{1} \mathrm{R}$ antagonist and 1, 4dihydropyridine calcium channel blockers. Among the synthesized molecules, eight showed both calcium channel and $\mathrm{AT}_{1} \mathrm{R}$ blocking activities. Interestingly, the effects of compound on Fig. 10 on $\mathrm{AT}_{1} \mathrm{R}$ were 100000 higher than losartan (Fig. 10).

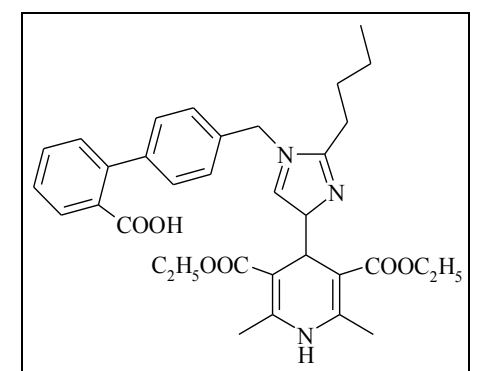

FIG. 10: DUAL CALCIUM CHANNEL AND AT1R BLOCKER

Compounds A and B (Fig. 11) exert potent dual activity, $\mathrm{AT}_{1} \mathrm{R}$ antagonism and partial proliferatoractivated receptor- $\gamma$ (PPAR $\gamma$ ) agonism and have desirable ADME properties ${ }^{29,30}$.
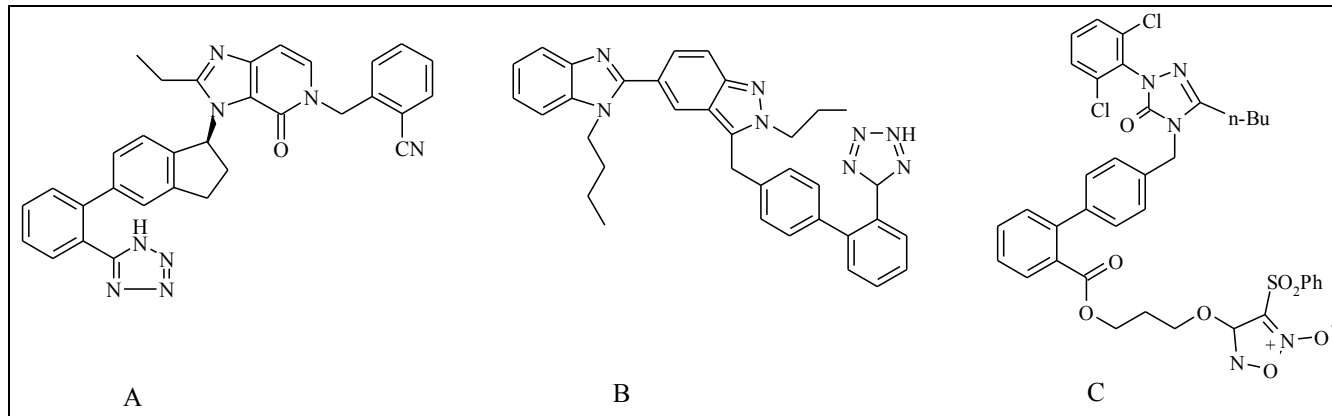

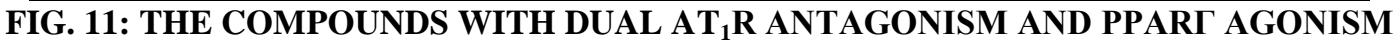

A series of nitric oxide donating derivatives of $[1,2,4]$ triazol-5(4H)-one exert both high $\mathrm{AT}_{1} \mathrm{R}$ antagonist activity and good maximum NO release; compound $\mathrm{C}$ is the most promising amongst them (Fig. 11) ${ }^{31}$.

$\mathrm{AT}_{2} \mathbf{R}$ Agonists and Antagonists: As mentioned above, for a long time the scientific community neglected $\mathrm{AT}_{2} \mathrm{R}$ and its major physiological role remained elusive ${ }^{32-34}$. However, the design and synthesis of the some selective $\mathrm{AT}_{2} \mathrm{R}$ antagonists and agonists (PD 123,319 ${ }^{35}$ CGP-42112A ${ }^{36}$, M024/C21 ${ }^{37}$, EMA401) that entered clinical trials for the treatment of neurophathic pain led to an understanding of the physiological role of this receptor and the design and synthesis of molecules possessing beneficial effects ${ }^{38,39}$.

Establishing ligands that will present enhanced selectivity for $\mathrm{AT}_{2} \mathrm{R}$ vs. $\mathrm{AT}_{1} \mathrm{R}$ is based on the fact that $\mathrm{AT}_{2} \mathrm{R}$ antagonizes the functions of $\mathrm{AT}_{1} \mathrm{R}$. Activation of $\mathrm{AT}_{2} \mathrm{R}$ leads to apoptosis, antiproliferation and vasodilation, whereas activation of $\mathrm{AT}_{1} \mathrm{R}$ leads to cellular growth, proliferation and vasoconstriction ${ }^{40}$. Wan et al., synthesized the first selective nonpeptide $\mathrm{AT}_{2} \mathrm{R}$ agonist M024/C21 (Fig. 12) by stepwise simplification of the nitrogen containing 
heterocyclic ring system ${ }^{41,42}$. The substitution of the thienyl-phenyl to the biphenyl scaffold (resembling L162.782, Fig. 12) produced the equipotent $\mathrm{C}$ showing that the two scaffolds are bioisosteric in these compounds ${ }^{43}$. Compound D, a derivative of L162.782, was synthesized by Liu et al., in an attempt to develop new $\mathrm{AT}_{2} \mathrm{R}$ agonists as novel antihypertensive candidates. The compound was superior to the reference drug losartan in SHRs and it had no significant impact in heart rate ${ }^{44}$.

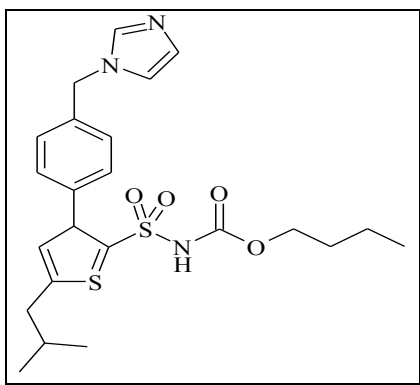

A

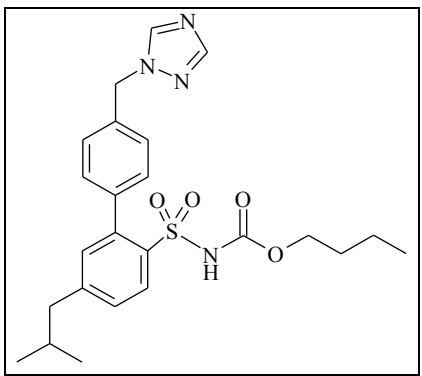

D

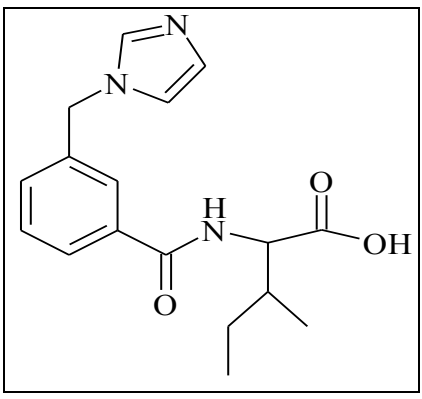

G

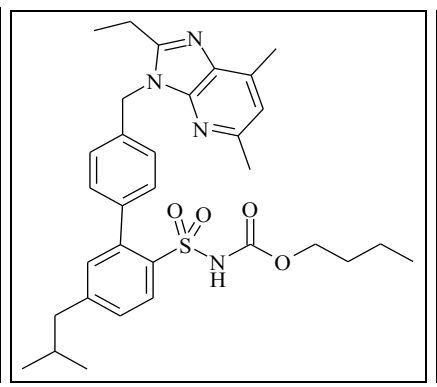

B

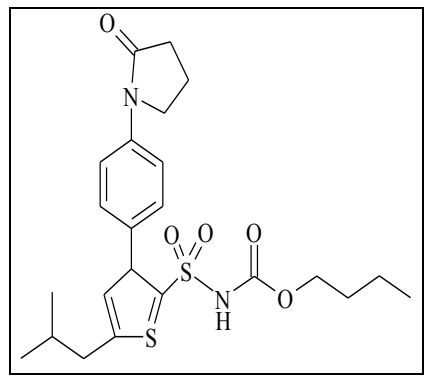

$\mathbf{E}$

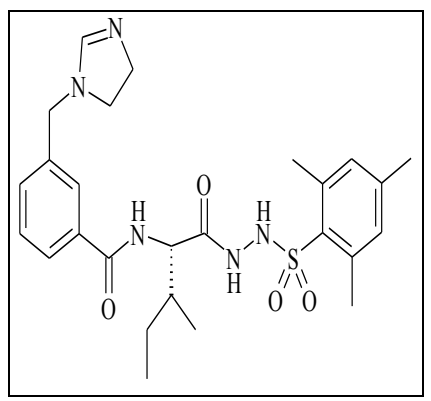

H

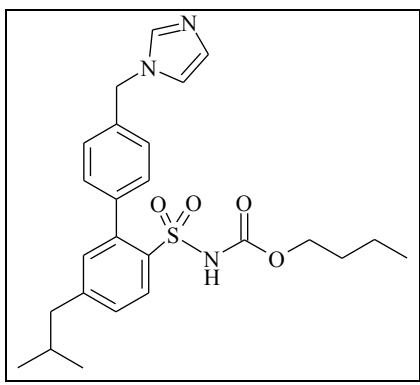

C

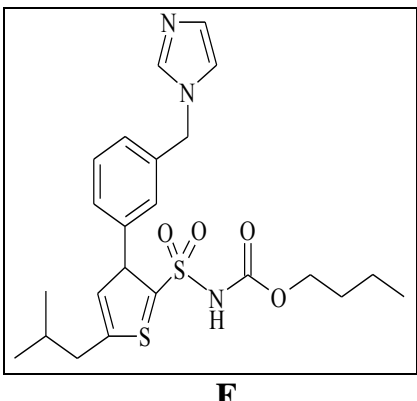

$\mathbf{F}$

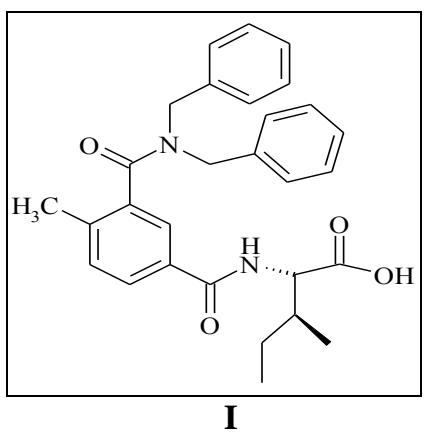

FIG. 12: CHEMICAL STRUCTURES OF THE FIRST SELECTIVE NONPEPTIDE AT ${ }_{2}$ R AGONISTS

Mahalingam et al., synthesized derivatives of $\mathrm{AT}_{2} \mathrm{R}$ agonist M024/C21 (Fig. 12) in an attempt to reduce the CYP450 inhibitory property. The best analogue prepared was compound E (Fig. 12) which induced neurite elongation in NG 108-15 cells and served as a potent and selective $\mathrm{AT}_{2} \mathrm{R}$ agonist ${ }^{45}$. These scientists also synthesized another analog of MO24/C21 - compound F, a selective $\mathrm{AT}_{2} \mathrm{R}$ antagonist, which is meta- rather than parasubstituted on the phenyl ring ${ }^{46}$.

Veron et al., used compound $\mathrm{G}$, which bears structural similarities with the C-terminal segment of angiotensine II, as a lead to synthesize sixteen new C-terminally modified analogues. Specifically, it contains a carboxylate group as Phe8, isoleucine side chain instead of benzene of $\mathrm{Phe}_{8}$ and imidazole ring as $\mathrm{His}_{6}$. Compound $\mathrm{H}$ proved the most active and was over 12-fold more potent than the lead compound G. All the synthesized compounds were evaluated for their human $\mathrm{AT}_{2} \mathrm{R}$ affinity in a radio ligand binding assay measuring the displacement of CGP-42112A,a selective $\mathrm{AT}_{2} \mathrm{R}$ agonist ${ }^{47}$. The compound G (Fig. 12) also was used by Behrends et al., to evaluate fifteen new synthetic derivatives, most of them showed higher activity than the lead compound, for example, the substance $\mathrm{I}^{48}$.

SAR of Angiotensine II Antagonists: There are some common scaffolds which all commercially available angiotensin II antagonist's posses (Fig. 13). 


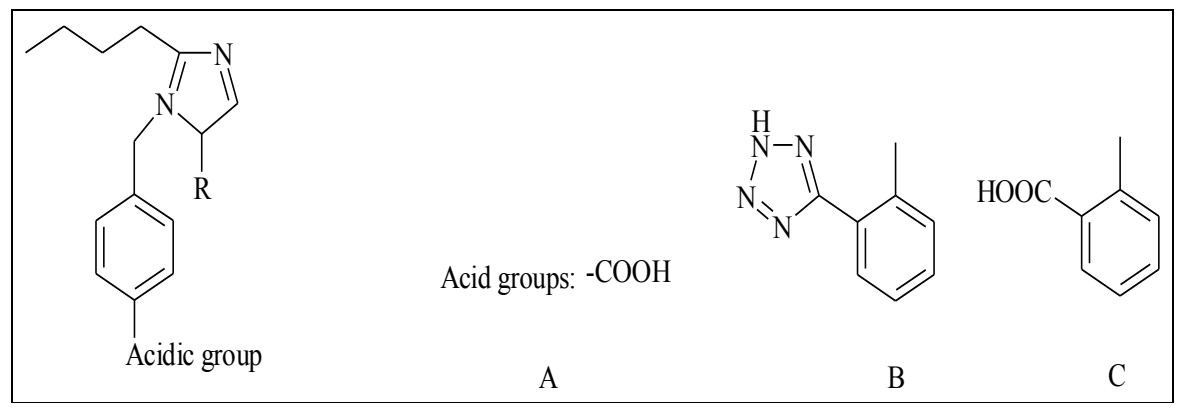

FIG. 13: COMMON SCAFFOLDS OF ANGIOTENSIN II ANTAGONISTS

1) The "acidic group" is thought to mimic either the $\mathrm{Tyr}_{4}$ phenol or the Asp 1 carboxylate of angiotensin II. Groups capable of such a role include the carboxylic acid (A), a phenyl tetrazole (B), or a phenyl carboxylate (C).

2) In the biphenyl series, the tetrazole and carboxylate groups must be in the ortho position for optimal activity (the tetrazole group is superior in terms of metabolic stability, lipophilicity, and oral bioavailability).

3) The $n$-butyl group of the model compound provides hydrophobic binding and most likely mimics the side chain of $\mathrm{Ile}_{5}$ of angiotensin II. As seen with candesartan and telmisartan, this $n$-butyl group can be replaced with a substituted benzimidazole ring.

4) The imidazole ring, or an isosteric equivalent, is required to mimic the $\mathrm{His}_{6}$ side chain of angiotensin II.

5) Substitution with a variety of $R$ groups including a carboxylic acid, methyl alcohol, an ether, or an alkyl chain is required to mimic the $\mathrm{Phe}_{8}$ of angiotensin II.

All of these groups are thought to interact with the $\mathrm{AT}_{2} \mathrm{R}$, some through ionic or ion-dipole bonds and others through hydrophobic interactions ${ }^{49}$. Multitarget drugs will certainly continue to be an interesting and fruitful approach and potentially can lead to more beneficial drugs with fewer side effects. At the moment only the structural requirements for $\mathrm{AT}_{1} \mathrm{R}$ antagonism are utilized.

A deeper knowledge on the molecular determinants on the $\mathrm{AT}_{2} \mathrm{R}$ agonism and antagonism in the future will offer to medicinal chemists enhanced versatility towards the design and synthesis of new generation of more potent compounds.
This effort to synthesize more selective drugs will certainly be continued. Another research activity which appears promising in the future is the synthesis of molecular hybrids and multi-target drugs. Due to the complexity of the systems that are involved in the cardiovascular diseases and others related to $\mathrm{AT}_{1} \mathrm{R}$ and $\mathrm{AT}_{2} \mathrm{R}$ the use of multitarget drugs will lead to beneficial aspects for treating these diseases avoiding in the same time side-effects.

\section{ACKNOWLEDGEMENT: Nil}

\section{CONFLICTS OF INTEREST: Nil}

\section{REFERENCES:}

1. Barreras A and Turner CG: Angiotensin II receptor blockers. Proc. (Bayl. Univ. Med. Cent.) 2003; 16(1): 123126.

2. Tahsin FK, Tzakos AG and Mavromoustakos T: Rational drug design and synthesis of molecules targeting the angiotensin II Type 1 and Type 2 Receptors. Molecules 2015; 20: 3868-3897.

3. Timmermans PB, Wong PC, Chiu AT, Herblin WF, Benfield P, Carini DJ et al.: Angiotensin II receptors and angiotensin II receptor antagonists. Pharmacol. Rev. 1993; 45: $205-213$.

4. Hongbao Ma and Yang Y: Enalapril. Researcher 2015; 7(1): 64-78.

5. Stasch JP, Knorr A, Hirth-Dietrich C, Kramer T, Hubsch $\mathrm{W}$, Dressel J et al.: Long-term blockade of the angiotensin II receptor in renin transgenic rats, salt-loaded Dahl rats, and stroke-prone spontaneously hypertensive rats. Arzneim-Forsch/Drug Research 1997; 47: 1016-1023.

6. Tamura K, Okuhira M, Amano H, Inokuma K-I, Hirata T, Mikoshiba I et al.: Pharmacological profiles of KRH-594, a novel nonpeptide angiotensin II-receptor antagonist. Journal of Cardiovascular Pharmacology 1997; 30: 607615.

7. Mochizuki S, Sato T, Furuta K, Hase K, Ohkura Y, Fukai C et al:: Pharmacological properties of KT3-671, a novel nonpeptide angiotensin II receptor antagonist. Journal of Cardiovascular Pharmacology 1995; 25: 22-29.

8. Bali A, Bansal Y, Sugumaran M, Saggu JS, Balakumar P, Kaur G et al.: Design, synthesis, and evaluation of novelly substituted benzimidazole compounds as angiotensin II receptor antagonists. Bioorganic and Medicinal Chemistry Letters 2004; 15: 3962-3965. 
9. Chang RSL, Siegl PKS, Clineschmidt BV, Mantlo NB, Chakravarty PK, Greenlee WJ et al:: In vitro pharmacology of L-158809, a new highly potent and selective angiotensin II receptor antagonist. Journal of Pharmacology and Experimental Therapeutics 1992; 262: 133-138.

10. Yoneyama M, Sugiyama A, Yoshida H, Satoh Y and Hashimoto K: Cardiovascular effects of L-158,809, a new angiotensin type 1 receptor antagonist, assessed using the halothane-anesthetized in vivo canine model. Japanese Journal of Pharmacology 2002; 89(2): 192-196.

11. Tokioka T, Shibasaki M, Inagaki O, Okazaki T, Yanasigawa I, Sato $\mathrm{N}$ et al.: Antihypertensive effects of YM358, a novel angiotensin II receptor antagonist, in rats with one-kidney, one clip hypertension. Japanese Journal of Pharmacology 1994; 64(1): 83

12. Tokioka T, Shibasaki M, Fujimori A, Matsuda-Satoh Y, Uchida W, Inagaki $\mathrm{O}$ et al:: Effects of YM358, an angiotensin II type $1\left(\mathrm{AT}_{1}\right)$ receptor antagonist, and enalapril on blood pressure and vasoconstriction in two renal hypertension models. Biology and Pharmacy Bulletin. 2000; 23(2): 174-181.

13. Jin D, Song K, Oka Y, Takai S, Shiota N and Miyazaki M: Pharmacological profiles of a novel non-peptide angiotensin II type 1 receptor antagonist HR 720 in vitro and in vivo. Japanese Journal of Pharmacology. 1997; 75: 259-266.

14. Agelis G, Resvani A, Koukoulitsa C, Tůmová T, Slaninová J, Kalavrizioti D et al.: Rational design, efficient syntheses and biologicalevaluation of $N, N^{\prime}-$ symmetrically bis-substituted butylimidazole analogs as a new class of potentangiotensin II receptor blockers. Eur. J. Med. Chem. 2013; 62: 352-370.

15. Agelis G, Resvani A, Matsoukas MT, Tselios T, Kelaidonis K, Kalavrizioti D et al.: Towards non-peptide ang II AT1 receptor antagonists based on urocanic acid: Rational design, synthesis and biological evaluation. Amino Acids 2011; 40: 411-420.

16. Zhang J, Wang JL, Yu WF, Zhou ZM, Tao WC, Wang YC et al:: Nonpeptidic angiotensin II AT1 receptor antagonists derived from 6-substituted aminocarbonyl and acylamino benzimidazoles. Eur. J. Med. Chem. 2013; 69: 44-54.

17. Da YJ, Yuan WD, Xin T, Nie YY, Ye Y, Yan YJ et al.: Synthesis and biological evaluation of new fluorine substituted derivatives as angiotensin II receptor antagonists with anti-hypertension and anti-tumor effects. Bioorg. Med. Chem. 2012; 20: 7101-7111.

18. Zhu W, Da Y, Wu D, Zheng H, Zhu L, Wang L et al.: Design, synthesis and biological evaluation of new 5-nitro benzimidazole derivatives as AT1 antagonists with antihypertension activities. Bioorg. Med. Chem 2014; 22: 2294-2302.

19. Ismail MAH, Abou El Ella DA, Abouzid KAM, AlAnsary GHA. Computer-based drug design, synthesis and biological evaluation of new pyrimidinone derivatives linked to arylpiperazine and 2'-carbethoxybiphenylylmethyl moeities as $\alpha_{1}$-adrenoceptor antagonists and angiotensin II AT1 receptor antagonists. Pharmazie. 2010; 65: 794-800.

20. Ismail MAH, Aboul-Enein MN, El-Azzouny AAE, Abouzid KAM and Ismail NSM: Design, synthesis, and antihypertensive evaluation of 2'-tetrazolyl and 2'carboxybiphenylylmethyl-pyrrolidine scaffolds substituted at their N1, C3, and C4 positions as potentialangiotensin II AT1 receptor antagonists. Med. Chem. Res 2015; 24: 442458.
21. Kowala MC, Murugesan N, Tellew J, Carlson K, Monshizadegan H, Ryan C et al:: Novel dual action AT1 and ETA receptor antagonists reduce blood pressure in experimental hypertension. Journal of Pharmacology and Experimental Therapeutics. 2004; 309(1): 275-284.

22. Murugesan N, Gu Z, Fadnis L, Tellew JE, Baska RA, Yang $\mathrm{Y}$ et al.: Dual angiotensin II and endothelin A receptor antagonists: synthesis of 2'-substituted N-3isoxazolyl biphenylsulfonamides with improved potency and pharmacokinetics. Journal of Medicinal Chemistry 2005; 48: 171-179.

23. Zhang H, Zhang D, Li W, Yao M, Darienzo C, Li YX et $a l .:$ Reduction of site-specific cyp3a-mediated metabolism for dual angiotensin and endothelin receptor antagonists in various in vitro systems and in cynomolgus monkeys. Drug Metabolism and Disposition 2007; 35(5): 795-805.

24. Li P, Fukuhara M, Diz DI, Ferrario CM and Brosnihan KB: Novel Angiotensin II $\mathrm{AT}_{1}$ receptor antagonist irbesartan prevents hromboxane $\mathrm{A}_{2}$-induced vasoconstriction in canine coronary arteries and human platelet aggregation. Journal of Pharmacology and Experimental Therapeutics 2000; 292(1): 238-246.

25. Pu Q, Amiri F, Gannon P and Schiffrin EL: Dual angiotensin-converting enzyme/neutral endopeptidase inhibition ont cardiac and renal fibrosis and inflammation in DOCA-salt hypertensive rats. Journal of Hypertension 2005; 23: 401-409.

26. Rastegar MA, Marchini F, Morazzoni G, Vegh A, Papp JG and Parratt JR: The effects of Z13752A, a combined ACE/NEP inhibitor, on responses to coronary artery occlusion; a primary protective role for bradykinin. British Journal of Pharmacology 2001; 29(4): 671-680.

27. Daull P, Blouin A, Belleville K, Beaudoin M, Arsenault D, Leonard H et al.: Triple VPI CGS 35601 reduces high blood pressure in low-renin, high-salt Dahl salt-sensitive rats. Experimental Biology and Medicine (Maywood) 2006; 231(6): 830-833.

28. Mojarrad JS, Zamani Z, Nazemiyeh H, Ghasemi S and Asgari D: Synthesis of novel 1,4-dihydropyridine derivatives bearing biphenyl-2'-tetrazole substitution as potential dualangiotensin II receptors and calcium channel blockers. Adv. Pharm. Bull 2011; 1: 1-9.

29. Casimiro-Garcia A, Heemstra RJ, Bigge CF, Chen J, Ciske FA, Davis JA et al.: Design, synthesis, and evaluation of imidazo[4,5-c]pyridin-4-one derivatives with dual activity at angiotensin II type 1 receptor and peroxisome proliferator-activated receptor- $\gamma$. Bioorg. Med. Chem. Lett 2013; 23: 767-772.

30. Lamotte Y, Faucher N, Sançon J, Pineau O, Sautet S, Fouchet et al.: Discovery of novel indazole derivatives as dual angiotensin II antagonists and partial PPAR- $\gamma$ agonists. Bioorg. Med. Chem. Lett. 2014; 24: 1098-1103.

31. Zhang Y, Zhou J, Pan W, Wu X, Wang S. Synthesis and biological study of 3-butyl-1-(2,6-dichlorophenyl)-1 $H$ $[1,2,4]$ triazol-5(4H)-one derivatives as anti-hypertension drugs. Lett. Drug Des. Discov. 2010; 7: 18-22.

32. Steckelings UM, Rompe F, Kaschina E, Namsolleck P, Grzesiak A, Funke-Kaiser $\mathrm{H}$ et al.: The past, present and future of angiotensin II type 2 receptor stimulation. J. Renin Angiotensin Aldosterone Syst. 2010; 11: 67-73.

33. Kaschina E and Unger T: Angiotensin AT1/AT2 receptors: Regulation, signaling and function. Blood Press 2003; 12: 70-88.

34. Steckelings UM, Kaschina $\mathrm{E}$ and Unger T: The AT2 receptor - A matter of love and hate. Peptides 2005; 26: 1401-1409. 
35. Blankley CJ, Hodges JC, Klutchko SR, Himmelsbach RJ, Chucholowski A, Connolly CJ et al:: Synthesis and structure-activity relationships of a novel series of nonpeptide angiotensin II receptor binding inhibitors specific for the AT2 subtype. J Med Chem 1991; 34: 3248-60.

36. Braszko JJ, Kułakowska A and Karwowska-Polecka W: CGP 42112A antagonism of the angiotensin II and angiotensin II(3-7) facilitation of recall in rats. Pharmacol Res 1998; 38(6): 461-8.

37. Wan Y, Wallinder C, Plouffe B, Beaudry H, Mahalingam $\mathrm{AK}, \mathrm{Wu} \mathrm{X}$ et al:: Design, synthesis, and biological evaluation of the first selective nonpeptide AT2 receptor agonist. J. Med. Chem 2004; 47: 5995-6008.

38. Rice ASC, Dworkin RH, McCarthy TD, Anand P, Bountra C, McCloud PI et al.: EMA401, an orally administered highly selective angiotensin II type 2 receptor antagonist, as a novel treatment for postherpetic neuralgia: a randomised, double-blind, placebo-controlled phase 2 clinical trial. The Lancet 2014; 383: 1637-1647.

39. McCarthy T: Development of EMA401 as an orallyadministered, highly-selective angiotensin II type 2 receptor antagonist for the treatment of neuropathic pain. $\mathrm{J}$. Peripher. Nerv. Syst. 2014; 19: 13-14.

40. Magnani F, Pappas CG, Crook T, Magafa V, Cordopatis P, Ishiguro $\mathrm{S}$ et al.: Electronic sculpting of ligand-GPCR subtype selectivity: the case of angiotensin II. ACS Chem. Biol 2014; 9: 1420-1425.

41. Wallinder C, Botros M, Rosenström U, Guimond MO, Beaudry H, Nyberg F et al., Selective angiotensin II AT2 receptor agonists: benzamide structure-activity relationships. Bioorg. Med. Chem 2008; 16: 6841-6849.
42. Steckelings UM, Larhed M, Hallberg A, Widdop RE, Jones ES, Wallinder C et al.: Non-peptide AT2-receptor agonists. Curr. Opin. Pharm. 2011; 11: 187-192.

43. Wu X, Wan Y, Mahalingam AK, Plouffe B, Botros M, Karlén A et al.: Selective angiotensin II AT2 receptor agonists: arylbenzylimidazole structure-activity relationships. J. Med. Chem 2006; 49: 7160-7168.

44. Liu J, Liu Q, Yang X, Xu S, Zhang H, Bai R et al.: Design, synthesis, and biological evaluation of $1,2,4$ triazole bearing 5-substituted biphenyl-2-sulfonamide derivatives as potential antihypertensive candidates. Bioorg. Med. Chem 2013; 21: 7742-7751.

45. Mahalingam AK, Wan Y, Murugaiah AMS, Wallinder C, $\mathrm{Wu}$ X, Plouffe B et al:: Selective angiotensin II $\mathrm{AT}_{2}$ receptor agonists with reduced CYP 450 inhibition. Bioorg. Med. Chem 2010; 18: 4570-4590.

46. Murugaiah AMS, Wu X, Wallinder C, Mahalingam AK, Wan Y, Sköld C et al.: From the first selective non-peptide $\mathrm{AT}_{2}$ receptor agonist to structurally related antagonists. J. Med. Chem 2012; 55: 2265-2278.

47. Veron JB, Joshi A, Wallinder C, Larhed M and Odell LR: Synthesis and evaluation of isoleucine derived angiotensin II $\mathrm{AT}_{2}$ receptor ligands. Bioorg. Med. Chem. Lett 2014; 24: 476-479.

48. Behrends M, Wallinder C, Wieckowska A, Guimond MO, Hallberg A, Gallo-Payet $\mathrm{N}$ et al:: $\mathrm{N}$-aryl isoleucine derivatives as angiotensin II $\mathrm{AT}_{2}$ receptor ligands. Chemistry Open 2014; 3: 65-75.

49. Behrends M, Wallinder C, Wieckowska A, Guimond MO, Hallberg A, Gallo-Payet $\mathrm{N}$ et al.: $N$-aryl isoleucine derivatives as angiotensin II $\mathrm{AT}_{2}$ receptor ligands. Chemistry Open 2014; 3: 65-75.

How to cite this article:

Drapak I, Tsapko T, Perekhoda L, Bereznyakova N and Kiz O: Historical overview, development and new approaches in design of angiotensin converting enzyme inhibitors and angiotensin receptor antagonists part II. Int J Pharm Sci Res 2017; 8(10): 4034-45.doi: 10.13040/IJPSR.0975-8232.8(10).4034-45.

All @ 2013 are reserved by International Journal of Pharmaceutical Sciences and Research. This Journal licensed under a Creative Commons Attribution-NonCommercial-ShareAlike 3.0 Unported License.

This article can be downloaded to ANDROID OS based mobile. Scan QR Code using Code/Bar Scanner from your mobile. (Scanners are available on Google Playstore) 